\title{
An Analysis on Negotiation Styles by Religious Beliefs
}

\author{
Yu-Te Tu (Corresponding author) \\ Department of Business Administration, Chungyu Institute of Technology \\ 40, Yi $7^{\text {th }}$ Rd. Keelung, Taiwan \\ Tel: 886-2-2423-7785 E-mail: suntu@ms18.hinet.net \\ Heng-Chi Chih \\ General Education Center, Wenzao Ursuline College of Languages \\ 900 Mintsu 1st Road Kaohsiung 807, Taiwan R.O.C.
}

Received: February 20, 2011 Accepted: March 28, 2011 doi:10.5539/ibr.v4n3p243

\begin{abstract}
Globalization and economic openness have contributed to increased international negotiations in the $21^{\text {st }}$ century. Despite the enthusiasm for increased global interaction and economic exchange, many people have found that cultural differences have hindered their ability to efficiently conduct business or negotiations due to their lack of understanding of the cultural differences in different countries.

This paper explores the impact of religious culture on negotiations. Specifically, we compare and contrast the effects of religious orientation on the negotiating styles of Greater China (Taiwan, Hong Kong and China). The research aims to investigate the role of religious culture as a factor in shaping the negotiation styles of people with different religious beliefs.

Casse and Deols' model of four negotiation styles was utilized in the research. The research found that there are different negotiation styles among the three countries which vary to significant degrees based upon the religious cultures within Taiwan, Hong Kong and China. These differences have imbued each country with a specific set of values and attitudes relating to their cultures. This study may help people develop more successful negotiation skills by giving them insight into the nuances of negotiations, and by identifying implications for negotiations and areas for future scholarly inquiry.
\end{abstract}

Keywords: Negotiation, Cultures, Greater China

\section{Introduction}

Globalization and economic openness have contributed to increased international engagement of countries in negotiations in the $21^{\text {st }}$ century. Randt (2004), a U.S. ambassador, noted in "Contact China," a publication of the U.S. government, that "China is not only the world's most populous nation, but it is also the world's fastest growing developing country. China will play an increasingly important role in re-shaping the economic landscape of Asia, the world's economically most dynamic region". As China emerges onto the international stage, it becomes necessary to know how this protective society will blend with the rest of the world. This blending is not just with western cultures, but also with cultures that originate from the very foundation of China itself.

In 2002, the International Monetary Fund's (IMF) report on International Financial Statistics and the World Trade Organization's (WTO) World Business Report indicated that Taiwan, Hong Kong, and China account for 10 percent of global merchandise trade in the world when Japan's share is only 5.0 percent. This is 4.1 percent more than Japan, highlighting China's role as the region's new key market. Presently, Greater China's economy has an enormous influence on the world economy (Ianchovichins \& Walmsley, 2003), and there are many companies in the world that are eager to engage in international business with this region. It is not easy, however, to trade with Greater China nor to negotiate with their businesses (Fan \& Zigang, 2004).

Gulbro and Herbig (1994) indicated that different cultures can generate distinct negotiation styles. This paper examines negotiation styles of people from three distinct cultures, those of Taiwan, Hong Kong and China - in terms of the impact on these cultures by the dominant religious traditions in each - Buddhism, Christianity and Muslim respectively. Knowledge about the impact of culture and religion on negotiation styles is an advantage for anyone involved in negotiations (Chang 2003).

Cultural negotiation literature is limited, particularly with respect to religious factors in general and to the effect of 
these factors on Taiwan, Hong Kong and China negotiation styles. The research aims to investigate the role of religious culture as a factor in shaping negotiation style of people with different religious beliefs. The negotiation styles of three religious beliefs will be examined and compared.

\section{Review of the Literature}

Due to its size and rapid economic development, China has become an increasingly important factor for world economy and growth. Many international companies have invested and expanded their businesses in China through joint ventures or mergers (Fan \& Zigang, 2004). In recent years, "Made in China" has become a matter of merchandising outsourcing options. It is estimated that China produces more than 20 percent of the world's refrigerators, 25 percent of its washing machines, 30 percent of its air-conditioners and televisions, 50 percent of its cameras, and 70 percent of the world's metal cigarette lighters (Thorpe, 2003). Today, in the consumer merchandise industry, China plays a key role, and has become an important source of goods due to its ability to produce goods less expensively. In 2001, Wal-Mart bought $\$ 10.3$ billion of goods from China, accounting for four percent of China's total exports that year. In 2002, the French retailer Carrefour purchased $\$ 1.6$ billion in merchandise from China, up 27 percent from 2001 (Hemerling \& Hsu, 2003).

On July 1, 1997, after 156 years of occupation, the British Crown Colony of Hong Kong was returned to the sovereignty of China. In a declaration, China announced the intention to maintain the present system in Hong Kong for 50 years under a "one country, two systems" policy, promising an elected legislature to govern Hong Kong with a high degree of autonomy (Liu, 2003). In 2001, Deutsche Bank indicated that Hong Kong serves as a financial center by serving China's investment needs and providing investment services.

Hong Kong's economic environment is being shaped by global economic conditions and regional cost-competitiveness over which it has little control. With China's entry into the World Trade Organization (WTO) in 2002, the mission of Hong Kong has become increasingly clear. As one researcher puts it, Hong Kong's goal is "to actively participate in bringing capitalism to China in alignment with the best international practices" (Loh, 2002, p. 7).

At the World Trade Organization (WTO) meeting in Doha, Qatar in November 2001, Taiwan and China were approved to become members of the WTO. Their entry into the WTO brought more trading opportunities for both of them as well as other WTO member countries (Boyarski, Fishman, Jopsephberg, \& Linn, 2002).

At present, China is already one of Taiwan's primary trading partners, and one of its major areas of investment. With each passing year, Taiwan's investments in China grow. Guo (2003) reported that Taiwan's investment in China increased to more than US $\$ 100$ billion between 1980 and 2001, and there were about 60,000 Taiwanese manufacturing companies and 500,000 Taiwanese managers operating in China from 1990 to 2000. China and Taiwan are developing closer economic ties, and these ties will further deepen in the future ("China", 2002).

As the economics within Greater China become more internally linked together, it becomes increasingly important to understand the nuances of each culture encompassed by this term. Although Taiwan, Hong Kong, and China largely originate from similar cultures and shared ancestry, their negotiation styles have been greatly influenced by their different socio-political systems (Prasad \& Rumbaugh, 2003). In recent history, China has been separated politically and economically, which has had a great influence on the development of the business climate of each area. The competing evaluations of the regions also highlight the role of ethnic and cultural influences in the development of business climates. An understanding of these different evolutions will help individuals adjust their strategies when conducting and negotiating business in these areas. Within these areas, the styles and skills relating to business negotiations have been greatly altered by the varied socio-political systems. The difference in value systems has imbued each one with a different view of foreign cultures. In conducting business, Taiwan typically follows American and Japanese practices, and Taiwan retains some connections with Japan, but in the academic world it has also been influenced by America (Bray \& Qin, 2001). Hong Kong had been a British colony at the end of the twentieth century, and Hong Kong typically follows British practices. The characteristics in Hong Kong are different from China and Taiwan (Bray \& Qin, 2001). China has adopted the command economic system and communism since 1945 (Kemenade, 1998). As of social policies at that time were closely guided by the Soviet Union, much of the education system, and especially the university sector, was restructured along Soviet lines (Hayhoe, 1999, p. 77). This continued until 1979, when Deng Xiaoping announced his "open door policy" (International Tax Review, 2007), resulting in China having more opportunities to contract with other countries. It is important to understand cross-cultural variations in negotiation of international business agreements among the three geographic areas.

Culture is commonly defined as "a set of shared values and beliefs that characterize national, ethnic, moral and other group behavior "(Faure and Sjostedt 1993; Craig and Douglas 2006; Adapa 2008). Culture also refers to individual 
cultures revealed through the food, songs, and stories that are exchanged with people outside of that region (Parra 2001). One further definition of culture is a pattern of shared basic assumptions that a group learned as it solved its problems of external adaptation and internal integration that has worked well enough to be considered valid, and therefore to be taught to new members as the appropriate ways to perceive, think, and feel with relation to those problems (Schein 1997). Simintiras and Thomas (1998) defined culture as "accepted values and norms that influence the way in which people think, feel, and behave. "Barbash and Taylor (1997) indicated that culture includes religion, gender, language, class, ethnicity, and sexual orientation. Since sub-cultures, cultures and super-cultures merge and evolve, while being less bounded than before; the idea of culture is more porous and varied than before (Barbash and Taylor 1997). Lee and Trim (2008) indicated that a shared organizational culture can help with the management of an international partnership arrangement, and senior managers will need to possess knowledge of the national cultural value traits of the people concerned.

Wheeler (2006) indicated that in the real world, negotiations are far more challenging, especially in their substantive and emotional aspects. In the broadest sense, negotiation is a process of communicating back-and-forth to discuss the issues to reach an agreement that is satisfactory to the parties involved (Gulbro and Herbig 1994; Foroughi 1998). Negotiation is a kind of social interaction with the goal of reaching an agreement between two or more parties, usually with different objectives or interests that they think are important (Fraser and Zarkada-Fraser 2002; Manning and Robertson 2003; Wheeler 2004a). Each negotiator's individual culture determines his or her epistemology, values, norms and behaviors (Simintiras and Thomas 1998; Hung 1998; Woo and Pru'homme 1999; Chang 2003).

Gulbro and Herbig (1994) indicated that different cultures can generate distinct negotiation styles. Differences in negotiating styles originate from the fact that every society places different degrees of importance on "relationship development, negotiating strategies, decision making methods, spatial and temporal orientations, contracting practices, and illicit behaviors such as bribery" (Acuff 1997: 19). These different styles in negotiation are the result of differences in communication, protocols, persuasion strategies, and personal characteristics, including accommodation, determination, flexibility, and adaptation (Hung 1998). Those specializing in negotiation need to be aware of and understand the negotiation styles of other people who live in different countries by studying their cultural beliefs and norms (Chang 2003).

Cross-cultural negotiations are more complex due to cultural factors, environments, languages, ideologies, and customs (Mintu-Wimsatt and Gassenheimer 2000; Hoffmann 2001). Because many negotiators may lack understanding of these cross cultural differences, they are often unsuccessful at reaching an agreement. Cultural aspects can be more of an obstacle than economic or legal factors (Gulbro and Herbig 1995). Every culture develops a unique negotiation style to handle conflicts that arise between those within and outside of that culture. Strategic alliances and multilateral negotiations have become essential to successful international relations. When conducting international business (Graham, Mintu and Rodgers 1994). Gulbro and Herbig (1998) indicated that for achieving successful agreements, negotiations are important in order to eliminate conflicting points of view between the representatives. A successful cross-cultural negotiation requires the skill of selecting the appropriate communication strategy and tactics. Successful negotiation requires not only acquiring technical communicative abilities, but also an understanding of the context of the negotiation by both parties (Korobkin 2000).

Upon completing the negotiations, the parties enter into a formal agreement. An agreement is the exchange of conditional promises, in which both parties agree to act in accordance with their promises (Martin 1997). Different cultures use different negotiation styles, and a party's styles in negotiating directly impact the terms of the final agreement. It is important to understand the various negotiation styles and the cultural issues that influence behavior during negotiation. There are numerous factors that can affect the results of the negotiating process. Among these are culture, personality, gender, experience, knowledge, and education of the parties involved in the negotiation process (Gulbro and Herbig 1994; Barbash and Taylor 1997; Simintiras and Thomas 1998; Hung 1998; Woo and Pru'homme 1999; Chang 2003).

Numerous studies have shown that culture is one of most important factors in cross-country negotiations (Salacuse 2005). An understanding of the differences and similarities of each culture by the negotiators is beneficial in facilitating communication and success in negotiation (Gannon 2001). When attempting cross-culture negotiations, the representatives need to be aware of and familiar with the different behaviors of representatives from other countries (Gulbro and Herbig 1999). During these negotiations, both parties must often change their tactics to meet the other party's style. Gulbro and Herbig (1995) also indicated "when negotiating internationally, this translates into anticipating culturally related ideas that are most likely to be understood by a person of a given culture". (p. 3)

To have a successful cross-cultural negotiation process it is necessary to fully understand the cultural values and assumptions of both parties. Additionally, the negotiators must see through the eyes of the other party's 
representatives to understand their goals (Fisher 1983). Wheeler (2004b) indicated that if the parties have not established shared definitions of why they are meeting and what they are negotiating, it will be more difficult to reach goals.

With the goal of helping individuals distinguish the various cultural differences of countries, Hofstede (1980) introduced his seminal theory of four cultural dimensions based on his earlier qualitative, phenomenological studies. This theory identifies four major cultural differences: power, uncertainty/avoidance, Collectivism characteristics, and masculinity/femininity (Hofstede 1980 and 1994). Hofstede's major proposition is that cultural differences impact business conduct, decision making and communication. Therefore, increased cultural awareness is important for international managers (Chang 2003). Hofstede and Bond (1988) added a fifth dimension to the cultural dimension model, which they identified as "Confucian dynamism," to distinguish between Chinese and Western cultural values. The five cultural dimensions were defined by Barry (2001: 35) as:

Power difference is the perceived degree of inequality among people. Uncertainty avoidance is the extent to which a society feels threatened by uncertain situations and avoids these situations by providing stable systems with formal rules. Collectivism characteristics are a social fabric in which each individual takes care of himself or herself in contrast with collectivism in which groups take care of the individual. Masculinity-Femininity reflects on whether the dominant values that are associated with the collection of money and things (masculinity) as contrasted with values associated with caring for others and quality of life (femininity). Confucian dynamism reflects whether the members of a society are short-term or long-term oriented in outlook.

Osman-Gani and Tan (2002) conducted an exploratory, quantitative study of cross-cultural impacts on negotiation styles of Chinese, Malay, and Indian managers living in Singapore. The four negotiation styles were developed by Casse and Deol (1985). These negotiation styles were more recently defined by Osman-Gani and Tan (2002: 825) as:

A factual style identifies facts in an unemotional manner, pays attention to details and all statements made during a negotiation, and places much importance on proof and facts as related to experience. An intuitive person is warm and animated when making statements, flexible and creative during negotiations, fluid and able to adapt to changing subjects and situations, and imaginative in projecting into the future. A normal person considers and weights facts according to a set of personal values; this person uses all the tools at his or her disposal, such as emotions, status, authority, and rewards, to come up with the best bargain. The analytical negotiator is strongly logical, tries to find cause-and-effect in all issues, and likes to weigh pros and cons thoroughly.

Based on the purpose of the study and the literature review described above, the research question of this study is: Do cultural characteristics, religious beliefs and individualistic-collectivist attitude of Taiwan, Hong Kong and China negotiators affect their negotiation styles?

\section{Data and Methodology}

This research is a causal comparative and explanatory study, and intended to examine, describe, and explore the differences and similarities of various negotiation styles in relation to the cultural differences in the three distinct countries, Taiwan, Hong Kong and China. The primary purpose of the study is to provide a more comprehensive understanding of the differences and similarities between culture and negotiation style among negotiators from Taiwan, Hong Kong and China.

The existing literature on the impact of culture on negotiation styles does not address the impact of religious belief on negotiation styles. Since the negotiation styles and cultures of these three countries have not been compared and comprehensively examined, this research provides a greater understanding by comparing the culture and negotiation styles of Taiwan, Hong Kong and China. The research utilizes a survey questionnaire to answer the research hypothesis. The research hypothesis is religious beliefs of Taiwan, Hong Kong and China negotiators have significant effects on negotiation styles employed.

A two-part questionnaire was developed by the researchers to measure variables related to negotiation styles, demographic background, collectivist attitude and religious affiliation. First, one of the models employed in this research examines the influence of culture on negotiation styles and was developed by Casse and Deol (1985). They developed a multidimensional model to measure four different negotiation styles (factual, intuitive, normative, and analytical negotiation styles). In the research model, these four negotiation styles were dependent variables. Religion is also a cultural element reflecting the group behavior (Barbash and Taylor 1997). The religious beliefs reflecting cultural differences are the independent variables of the research model.

There are 10 questions designed to examine each negotiation style (factual negotiation style, intuitive negotiation style, normative negotiation style, and analytical negotiation style) that are analyzed on the five-point Likert scale. 
There are five options for each statement: 5. "Always" (around 100\% of the time); 4. "Often" (around $75 \%$ of the time); 3. "Occasionally" (around 50\% of the time); 2. "Seldom" (around 25\% of the time); 1 . "Never" (around $0 \%$ of the time). In total, there are 40 questions for the four negotiation styles.

The model includes socio-demographic characteristic for the participants including gender, age, education, work experiences, and years of residence in foreign countries as additional attributes. For the data collection of demographic variables, the participants are provides the questions as follows. Education (as a nominal variable): $1=$ "High School Diploma or Equivalent"; 2= "Associate Degree"; 3= "Bachelor Degree"; 4= "Graduate Degree". Religion (as a nominal variable): $1=$ "Buddhist"; $2=$ "Christian"; $3=$ "Moslem"; $4=$ "Others". Gender is defined as a dichotomous variable ( $1=$ Male; $2=$ Female). Age is defined as a nominal variable $(1=$ under $35 ; 2=35-45 ; 3=46-55$; $4=$ over 55). As mentioned in the introduction section, work experience and years of negotiation experience are defined as nominal variables $(1=$ under $5 ; 2=5-10 ; 3=11-20,4=$ over 20$)$. Years of residence in foreign countries is defined as a nominal variable ( $1=$ none; $2=1-3 ; 3=4-6 ; 4=$ over 6$)$.

For this study, the accessible population was chosen from public companies listed under the Taiwan Stock Exchange Corporation (TSEC), Hong Kong Exchanges and Clearing Limited (HKEx), Shenzhen Stock Exchange (SSE) and Shanghai Stock Exchange in China. In 2005, there were 700 listed companies in the Taiwan Security Exchange Corporation (TSEC), and all listed companies were classified into eight sectors, including cement and ceramics, foods, plastics and chemical, textiles, electric \& machinery, paper and pulp, construction, and financial. There were 911 listed companies on the Hong Kong Exchanges and Clearing Limited (HKEx), and all companies were classified into six sectors, including financials, utilities, real estate, industries, hotels, and others. In Mainland China, there were 585 listed companies (including A stock: 530 companies and B Stock: 55 companies) in the Shenzhen Stock Exchange (SSE), and all companies are classified into six sectors, including industry, business, financials, real estate, utilities, and others. There were 872 listed companies (including A stock: 820 companies and B Stock: 52 companies) in the Shanghai Stock Exchange, and all companies were classified into five sectors, including industry, business, real estate, utilities, and others. In total, there were 3,068 listed public companies in Taiwan, Hong Kong, and Mainland China. Any company listed on these markets had the potential to be included in this study.

Data was collected using an online survey technique. Usually, the average response rate of online survey is not high. Therefore, a large number of the initial e-mail invitations for this study were sent out to ensure a large enough number of online survey responses were obtained. The number of listed companies in the stock markets in Taiwan, Hong Kong, and Mainland China was 3,068. With an accessible population of 9,204 including CEOs and sales and purchase managers, the desired sample size was 4,605 in order to increase generalization and reduce sampling errors

To obtain the desired initial sample size of 4,605, 1, 535 companies were chosen, and each company's CEOs and sales and purchase managers were randomly selected from listed companies of stock markets in Taiwan, Hong Kong, and Mainland China. Invitation e-mails were sent to 4,605 participants. All information, such as the names of CEOs and sales and purchase managers, and e-mail addresses of listed companies were obtained through the website of the Taiwan Stock Exchange Corporation (TSEC), Hong Kong Exchanges and Clearing Limited (HKEx), Shenzhen Stock Exchange (SSE), and Shanghai Stock Exchange. The survey was accessible on the Internet without direct contact with the researcher. The CEOs and sales and purchase managers of the sample population were invited to participate via an e-mail that explained the research and included a link to the survey website. The questionnaire was posted on the website, "www.my3q.com" in English, traditional Chinese, and simplified Chinese. The researcher asked respondents to return the surveys within 30 days by sending an e-mail to "www.my3q.com" website.

Three hundred and fifty companies were considered from the 700 listed companies on the Taiwan Stock Exchange Corporation. Three e-mails were sent, one of each to each company's CEOs and sales and purchase managers. There were 1050 potential respondents in total. The number of companies that were considered from the 911 listed on the Hong Kong Exchanges and Clearing Limited (HKEx) were 456. The CEOs and sales and purchase managers of each company were contacted by e-mail. The total number of potential respondents for this study from Hong Kong was 1,368. Two hundred and sixty-five companies were considered from the 530 listed on the Shenzhen Stock Exchange (SSE) of A Stock. There were 795 subjects from the Shenzhen Stock Exchange (SSE) of A Stock. Twenty-eight companies were considered from the 55 listed companies in the Shenzhen Stock Exchange (SSE) of B Stock. The CEOs and sales and purchase managers of each company were contacted by e-mail. This sample had 84 subjects. Four hundred and ten companies were considered from the 820 listed on the Shanghai Stock Exchange of A Stock. The CEOs and sales and purchase managers were contacted by e-mail. There were 1,230 subjects for this study from the Shanghai Stock Exchange of A Stock. Twenty-six companies were considered from the 52 listed in the Shanghai Stock Exchange of B Stock. The CEOs and sales and purchase managers of each company were contacted by e-mail. There were 78 subjects from the Shanghai Stock Exchange of B Stock. 
The research objectives are as follows: (1) to provide a more comprehensive understanding of the differences and similarities between culture, and negotiation styles among negotiators from Taiwan, Hong Kong and China; (2) to investigate the relationship between cultural characteristics, religious beliefs, and their perceived differences in negotiation styles of Taiwan, Hong Kong and China.

\section{Results}

This research examined the impact of cultural factors (independent variables) on negotiation styles (dependent variables). The research used a respondent self-reported survey questionnaire to collect the data and to test the relationship between dependent and independent variables, and the results are presented from the statistical analysis that was used to analyze the four negotiation styles, religion, collectivist and socio-demographic characteristics.

Cronbach's coefficient $a$ was used to analyze variables that are composed of several scale items. In this study, the internal consistency reliability was measured by using Cronbach's coefficient $a$ according to the mean or average correlation of each item with every other item. Leech, Barrett, and Morgan (2005) recommend that Cronbach's $a$ value should be above 0.70, but Lin (2006) states that Cronbach's $a$ value in basic research should be at least 0.80 .

The Cronbach's $a$ value of analytical negotiation style was 0.92 ; The Cronbach's $a$ value of normative negotiation style was 0.87; The Cronbach's $a$ value of factual negotiation style was 0.88 , The Cronbach's $a$ value of intuitive negotiation style was 0.86 . The internal consistency reliability of instruments of this study was therefore considered sufficient for social science research, as shown in Table 1.

Table 2 shows that among the 609 respondents, 453 (74.4\%) were male and $156(25.6 \%)$ were female. In this study, $243(39.9 \%)$ earned an annual income of less than US $\$ 35,000$. There were $140(23.0 \%)$ who earned from US $\$ 35,001$ to $\$ 50,000 ; 164(26.9 \%)$ who earned from US $\$ 50,001$ to $\$ 65,000$; and $62(10.2 \%)$ who earned more than US $\$ 65,000$. In this study, 39 respondents (6.4\%) held a high school diploma or equivalent; 23 respondents (3.8\%) had an associate degree; 319 respondents (52.4\%) were college or university graduates; and 228 respondents (37.4\%) had a graduate degree. In terms of religion, 165 respondents (27.1\%) were Buddhist; 67 (11.0\%) were Christian; 38 (6.2\%) were Muslim; and $339(55.7 \%)$ were others. The largest number, nearly a third, $168(27.6 \%)$ of respondents were from Taiwan; 179 (29.4\%) were from Hong Kong; and 262 (43.0\%) were from Mainland China. Respondents' age ranged from 35 to 45 years old. There were $169(27.7 \%)$ respondents under 35 years old; $258(42.4 \%)$ between 35 and 45 years old; $132(21.7 \%)$ from 46 to 55 years old; and $50(8.2 \%)$ who were older than 55.

From the mean difference of the Post Hoc Test of ANOVA, a statistically significant difference was found between religious beliefs and normative style, $F(3,605)=20.961, p=.000$ as shown in Table 3 . As shown in Table 4, a multiple comparisons of Post Hoc Tests showed that there was a significant difference between Buddhist and Christian, and the mean difference was .613, and there was a significant difference between Christian and Muslim, and the mean difference was -.425 .

From the mean difference of the Post Hoc Test of ANOVA, a statistically significant difference was found between religious beliefs and analytical style, $F(3,605)=27.191, p=.000$ as shown in Table 5. As shown in Table 6, a multiple comparisons of Post Hoc Tests showed that there was a significant difference between Buddhist and Christian, and the mean difference was -.410; there was a significant difference between Buddhist and Muslim, and the mean difference was -.894; there was a significant difference between Christian and Muslim, and the mean difference was -.484.

From the mean difference of the Post Hoc Test of ANOVA, a statistically significant difference was found between religious beliefs and analytical style, $F(3,605)=28.107, p=.000$ as shown in Table 7. As shown in Table 8, a multiple comparisons of Post Hoc Tests showed that there was a significant difference between Buddhist and Muslim, and the mean difference was .903; there was a significant difference between Christian and Muslim, and the mean difference was 1.131 .

From the mean difference of the Post Hoc Test of ANOVA, a statistically significant difference was found between religious beliefs and analytical style, $F(3,605)=28.266, p=.000$ as shown in Table 9. As shown in Table 10, a multiple comparisons of Post Hoc Tests showed that there was a significant difference between Buddhist and Muslim, and the mean difference was .748; there was a significant difference between Christian and Muslim, and the mean difference was .683.

\section{Discussion and conclusion}

This section presents a discussion of the results, presented with an interpretation of findings and the practical implications pertaining to Taiwan, Hong Kong and China negotiators. The next section reviews this study and provides certain limitations, recommendations for future studies, and the conclusions. 
From the view point of normative style, negotiators from Buddhist group prefer to employ the normative negotiation style more so than negotiators from Christian group, and negotiators from Muslim group mostly employ the normative negotiation style more so than negotiators from Christian group. From the view point of analytical style, negotiators from Muslim group prefer to employ the analytical negotiation style more so than negotiators from Christian and Buddhist groups. From the view point of factual style, negotiators from Buddhist group prefer to employ the factual negotiation style more so than negotiators from Muslim group, and negotiators from Christian group mostly employ the normative negotiation style more so than negotiators from Muslim group. From the view point of intuitive style, negotiators from Buddhist group prefer to employ the intuitive negotiation style more so than negotiators from Muslim group, and negotiators from Christian group mostly employ the normative negotiation style more so than negotiators from Muslim group.

From the results, therefore, it can be concluded that the interaction between religious beliefs is a significant variable affecting the normative, analytical, factual and intuitive negotiation styles. An addition to Casse and Deol (1985) negotiation styles, there is the ideological negotiation style which has its roots in a negotiator's strong ideological levels of devotion and belief. The strong correlation between negotiation style and religious belief points to the importance of considerations for and awareness of the negotiators' ideological or religious beliefs and levels of devotion. Knowledge about and respect for the religion of the negotiators could develop trust and mutual respect. This, in turn, could result in a higher probability of successful agreements.

The findings of this study are limited to college students in Taiwan, Hong Kong and China. This study was constrained by limited human resources, financial resources, and time; therefore, the study only adopted a quantitative research method and employed a self-reporting questionnaire to conduct the survey. Future studies could compare the differences and similarities of negotiation styles among several countries and/or could include more than three religions and sets of related ideological beliefs with a qualitative method to enhance the findings of the quantitative method.

Osman-Gani and Tan (2002) indicated that subtle differences and nuances could make all the difference in cross-cultural negotiations, and Casse (1981) stated, "the parties involved belong to different cultures, and therefore, do not share the same ways of thinking, feeling, and behaving" (p. 152). The objective of this study was to identify the critical influences on cross-cultural negotiation styles, and the results of this study indicate that all of the contexts in Taiwan, Hong Kong and China are important for negotiation. The findings of this study not only expand the current knowledge of negotiation styles among Taiwan, Hong Kong and China, but also may provide reference to people who want to conduct negotiation in these three countries. The researchers hope that this study will improve the general understanding of Greater China negotiation styles and help people develop better strategies in negotiation.

\section{References}

Acuff, F. L. (1997). How to negotiate anything with anyone anywhere around the world, New York: AMACOM.

Adapa, S. (2008). Adoption of internet shopping: Cultural considerations in India and Australia. Journal of Internet Banking and Commerce, 13(2), 1-17.

Barbash, I., \& Taylor, L. (1997). Cross-cultural filmmaking. Berkeley and Los Angels, California: University of California Press.

Barry, S. (2001). Information sharing in global supply chain systems. Journal of Global Information Technology Management, 4(3), 27-50.

Bazerman, M. H., Curhan, J. R., Moore, D. A. \& Valley, K. L. (2000). Negotiation. Annual Review of Psychology, 51, 279-314.

Bowman, C., \& Ambrosini, V. (1997). Using single respondents in strategy research. British Journal of Management, 8, 119-31.

Boyarski, J. B., Fishman, R. M., Jopsephberg, K., \& Linn, J. (2002). World trade organization welcoming Taiwan as a member. Intellectual Property \& Technology Law Journal, 14(2), 35-37.

Bray, M., \& Qin, G. (2001). Comparative education in greater China: contexts, characteristics, contrasts and contributions. Comparative Education, 37(4), 451-473.

Casse, P. (1981). Training for the cross cultural mind. Washington, DC: Society for Inter-Cultural Education, Training and Research, Intercultural Press.

Casse, P., \& Deol, S. (1985). Managing intercultural negotiations: Guidelines for trainers and negotiators, International Society for Intercultural Educa. 
Chang, L. C. (2003). An examination of cross-cultural negotiation: Using Hofstede framework. Journal of American Academy of Business, 2(2), 567-570.

China. (2002). Taiwan investing more in mainland. Asia Times. [Online] Available: http://www. atimes. com/china/DE31Ad02. Html (December 21, 2010)

Craig, C. S. \& Douglas, S. P. (2006). Beyond national culture: implications of cultural dynamics for consumer research. International Marketing Review, 26(3), 322-342.

Faure, G. O., \& Sjostedt, G. (1993). Culture and negotiation: An introduction, Newbury Park: Sage Publications.

Fan, P., \& Zigang, Z. (2004). Cross-cultural challenges when doing business in China. Singapore Business Review, 26(1), 81-90.

Fisher, G. (1983). International negotiation: Cross-cultural perception. The Humanist, 43(11), 14-18.

Foroughi, A. (1998). Minimizing negotiation process losses with computerized negotiation support systems. Journal of Applied Business Research, 14(4), 15-27.

Gannon, M. J. (2001). Understanding global cultures, Newbury Park: Sage Publications, Inc.

Graham, J. L., Mintu, A. T., \& Rodgers, W. (1994). Explorations of negotiation behaviors in ten foreign cultures using a model developed in the United States. Management Science, 40(1), 72-95.

Gulbro, R. D., \& Herbig, P. (1994). The effect of external influences in the cross-cultural negotiation process. Journal of strategic change, 3, 329-340.

Gulbro, R. D., \& Herbig, P. (1995). International negotiating behavior of small firms. Journal of business and entrepreneurship, 7(2), 85-91.

Gulbro, R.D., \& Herbig, P. (1998). Cultural differences in international negotiating. International Journal of Value-Based Management, 11,265-73.

Gulbro, R. D., \& Herbig, P. (1999). Cultural differences encountered by firms when negotiating internationally. Industrial Management + Data Systems, 99(2).

Guo, J. J. (2003). Comments on Taiwan and the political implications of cross-strait economic relations. Peace Forum. [Online] Available: www. peaceforum. org. tw/onweb. jsp?webno $=3333333322 \&$ webitem_no $=649$ (December 21, 2010)

Hayhoe, R. (1999). China's universities 1895-1995: a century of cultural conflict (Hong Kong, Comparative Education Research Centre, The University of Hong Kong).

Hemerling, J., \& Hsu, H. (2003). Aim high, act fast: The China sourcing imperative. The Boston Consulting Group., [Online] Available: http://www. bcg. fr/missions/content/pdf/AimHighActFast. pdf (December 21, 2010)

Hoffmann, G. (2001). When scientists or engineers negotiate. Research Technology Management 44(6): 13-16.

Hofstede, G. (1980). Culture's consequences: international differences in work-related values, Beverly Hill: CA Sage Publications.

Hofstede, G., \& Bond, M. H. (1988). The Confucius connection: From cultural roots to economic growth. Organizational Dynamics, 16(4), 4-21.

Hofstede, G. (1994). Cultures and organizations: Software of the mind: intercultural cooperation and its importance for survival. London: Harper Collins.

Huang, R. (1997). China: a macrohistory, Armonk, NY: M. E. Sharpe.

Hung, C. L. (1998). Canadian business pursuits in the PRC, Hong Kong and Taiwan, and Chinese perception of Canadians as business partners. Multinational Business Review, 6(1), 73-83.

Ianchovichina, E., \& Walmsley, T. (2003). Impact of China's accession on east Asia, World Bank Policy Research Working Paper.

International Tax Review. (2007). Cultural evolution: the tax business in China, London: International Tax Review.

Kemenade, W. V. (1998). China, Hong Kong, Taiwan, Inc. : the dynamics of a new empire, Center for Strategic and International Studies (CICS), and Massachusetts Institute of Technology.

Kerlinger, F., \& lee, H. (2000). Foundations of Behavioral research. $4^{\text {th }}$ ed, Wadsworth, Thomson learning: Australia.

Korobkin, R. (2000). A positive theory of legal negotiation. George Law Journal, 88(6), 1789-1732. 
Lee, Y. I., \& Trim, R. J. (2008). The link between cultural value systems and strategic marketing; Unlocking the mindset of Japanese and South Korean managers. Cross Cultural Management, 15(1), $62-88$.

Liu, C. K. H. (2003). China. Asia Times. [Online] Available: http://www. atimes. com/atimes/China/EE21Ad02. $\mathrm{Html}$ (December 22, 2010)

Loh, C. (2002). Hong Kong's SMEs. CLSA Emerging Markets. [Online] Available: http://www. civic-exchange. org/03publication/HKPrimer. pdf (December 23, 2010)

Manning, T., \& Robertson, B. (2003). Influencing and negotiating skills: Some research and reflections - Part I: Influencing strategies and styles. Industrial and Commercial Training, 35(1), 11-16.

Martin, D. (1997). Contractual aspects of cross cultural negotiations. Marketing Intelligence and Planning 15(1): 19-36.

Ministry of Economic Affairs (MOEA). 2008. Trade Statistics. [Online] Available: http://cus93.trade.gov.tw/bftweb/FSC3/FSC3040R.ASP?rptName=FSC3040R\&typ=A\&BYEAR=200801\&EYEAR $=200812 \&$ USER_ID $=\&$ intType $=1($ December 23,2010$)$

Mintu-Wimsatt, A., \& Gassenheimer, J. B. (2000). The moderating effects of cultural context in buyer-seller negotiation. The Journal of Personal Selling and Sales Management, 20(1), 1-9.

Mintu-Wimsatt, A., \& Gassenheimer, J. B. (2002). The impact of demographic variables on negotiators' problem-solving approach: A two country study. Journal of Marketing Theory and Practice, 10(1), 23-35.

Nunnally, J.C. (1978). Psychometric Theory. $2^{\text {nd }}$ ed, New York: McGrow-Hill.

Osman-Gani, A. M., \& Tan, J. S. (2002). Influence of culture on negotiation styles of Asian managers: An empirical study of major cultural/ethic group in Singapore. Thunderbird International Business Review, 44(6), 819-840.

Prasad, E., \& Rumbaugh, T. (2003). Beyond the great wall. Finance \& Development, $40(4), 46$.

Salacuse, J. W. 2005. Negotiating: The top ten ways that culture can affect your negotiation. Ivey Business Journal Online 1-6.

Schein, E. H. (1997). Organizational culture and leadership, CA: Jossey-Bass Inc.

Simintiras, A. C., \& Thomas, A. H. 1998. Cross-cultural sales negotiations: A literature review and research propositions. International Marketing Review, 15(1), 10-36.

Thorpe, J. (2003). The China factor. National Post. [Online] Available: http://www.yangtzetelecom. com/i/pdf/ChinaFactor_E. pdf (December 25, 2010)

$\mathrm{Tu}$, J. T. (2007). Impact of Culture on International Business Negotiations: A Cross-Cultural Comparison of Taiwan, Hong Kong and Mainland China. PhD diss., Lynn University.

Tu, J. T., \& Farazmand, F. (2007). Impact of Culture on International Business Negotiations: A Cross-Cultural Comparison of Taiwan, Hong Kong and Mainland China. Paper presented at the Proceeding of International Conference on Business, Management and Economics (ICBME), June 13-17, in Yasar University, Izmir, Turkey.

Wheeler, M. (2006). Is teaching negotiation too easy, too hard, or both? Negotiation Journal, 22(2), 187-198.

Wheeler, M. (2004a). Anxious moments: openings in negotiation. Negotiation Journal, 20(2), 153-170.

Wheeler, M. (2004b). Awareness and action in critical moments. Negotiation Journal, 20(2), 349-365.

Woo, H. S., \& Prud'homme, C. (1999). Cultural characteristics prevalent in the Chinese negotiation process. European Business Review, 99(5), 313-315.

Table 1. Reliability Statistics of Collectivism Characteristics and Negotiation Styles

\begin{tabular}{|l|c|c|}
\hline \multicolumn{1}{|c|}{ Variables } & Items & Cronbach's $\boldsymbol{a}$ Coefficient \\
\hline Normative Negotiation Style & 6 & 0.83 \\
\hline Normative Negotiation Style & 6 & 0.83 \\
\hline Normative Negotiation Style & 6 & 0.83 \\
\hline Normative Negotiation Style & 6 & 0.83 \\
\hline
\end{tabular}


Table 2. Frequency Distribution of Socio-Demographic Characteristics

\begin{tabular}{|l|l|c|c|}
\hline \multicolumn{2}{|c|}{ Socio-Demographic Characteristics } \\
\hline & \multicolumn{1}{|c|}{ Frequency } & Percent \\
\hline & Male & 453 & 74.4 \\
\hline & Female & 156 & 25.6 \\
\hline Last Degree Completed & High School Diploma or Equivalent & 39 & 6.4 \\
\hline & Associate Degree & 23 & 3.8 \\
\hline & Bachelor Degree & 319 & 52.4 \\
\hline & Graduate Degree & 228 & 37.4 \\
\hline Religious Affiliation & Buddhist & 165 & 27.1 \\
\hline & Christian & 67 & 11.0 \\
\hline & Muslim & 38 & 6.2 \\
\hline & Other & 339 & 55.7 \\
\hline Regions of Birth & Taiwan & 168 & 27.6 \\
\hline & Hong Kong & 179 & 29.4 \\
\hline & Mainland China & 262 & 43.0 \\
\hline Age & Under 35 & 169 & 27.7 \\
\hline & $35-45$ & 258 & 42.4 \\
\hline & $46-55$ & 132 & 21.7 \\
\hline & Above 55 & 50 & 8.2 \\
\hline
\end{tabular}

Table 3. One-way analysis of variance summary for normative negotiation style

\begin{tabular}{|l|c|c|c|c|c|}
\hline & Sum of Squares & df & Mean Square & F & Sig. \\
\hline Between Groups & 26.840 & 3 & 8.947 & 20.961 & .000 \\
Within Groups & 258.226 & 605 & .427 & & \\
Total & 285.066 & 608 & & & \\
\hline
\end{tabular}

Table 4. Multiple comparisons of Post Hoc tests on normative negotiation style for religion

\begin{tabular}{|c|c|c|c|c|}
\hline Dependent Variable & Religion (I) & Religion (J) & Mean Difference (I-J) & Post Hoc Test \\
\hline \multirow[t]{9}{*}{ Normative } & Buddhist & Christian & $.61250(*)$ & \multirow{9}{*}{$\begin{array}{l}\text { Buddhist }>\text { Christian } \\
\text { Muslim }>\text { Christian }\end{array}$} \\
\hline & & Muslim & .18705 & \\
\hline & & Other & -.06585 & \\
\hline & Christian & Buddhist & $-.61250(*)$ & \\
\hline & & Muslim & $-.42545(*)$ & \\
\hline & & Other & $-.67835\left(^{*}\right)$ & \\
\hline & Muslim & Buddhist & -.18705 & \\
\hline & & Christian & $.42545(*)$ & \\
\hline & & Other & -.25290 & \\
\hline
\end{tabular}

* The mean difference is significant at the .05 level.

Table 5. One-way analysis of variance summary for analytical negotiation style

\begin{tabular}{|l|c|c|c|c|c|}
\hline & Sum of Squares & df & Mean Square & F & Sig. \\
\hline Between Groups & 35.507 & 3 & 11.836 & 27.191 & .000 \\
Within Groups & 263.346 & 605 & .435 & & \\
Total & 298.853 & 608 & & & \\
\hline
\end{tabular}


Table 6. Multiple comparisons of Post Hoc tests on analytical negotiation style for religion

\begin{tabular}{|c|c|c|c|c|}
\hline Dependent Variable & Religion (I) & Religion (J) & Mean Difference (I-J) & \multirow{2}{*}{ Post Hoc Test } \\
\hline Analytic & Buddhist & Christian & $-.40991\left(^{*}\right)$ & \\
\hline & & Muslim & $-.89424\left(^{*}\right)$ \\
\hline & & Other & $-.45604\left(^{*}\right)$ \\
\hline & Christian & Buddhist & $.40991\left(^{*}\right)$ & \multirow{2}{*}{ Muslim > Christian > Buddhist } \\
\hline & & Muslim & $-.48433\left(^{*}\right)$ & \\
\hline & & Other & -.04613 \\
\hline & Muslim & Buddhist & $.89424\left(^{*}\right)$ \\
\hline & & Christian & $.48433\left(^{*}\right)$ \\
\hline & & Other & $.43820\left(^{*}\right)$ & \\
\hline
\end{tabular}

* The mean difference is significant at the .05 level.

Table 7. One-way analysis of variance summary for factual negotiation style

\begin{tabular}{|l|c|c|c|c|c|}
\hline & Sum of Squares & df & Mean Square & F & Sig. \\
\hline Between Groups & 34.871 & 3 & 11.624 & 28.107 & .000 \\
Within Groups & 250.196 & 605 & .414 & & \\
Total & 285.066 & 608 & & & \\
\hline
\end{tabular}

Table 8. Multiple comparisons of Post Hoc tests on factual negotiation style for religion

\begin{tabular}{|c|c|c|c|c|}
\hline Dependent Variable & Religion (I) & Religion (J) & Mean Difference (I-J) & Post Hoc Test \\
\hline \multirow[t]{9}{*}{ Factual } & Buddhist & Christian & -.22858 & \multirow{9}{*}{$\begin{array}{l}\text { Buddhist }>\text { Muslim } \\
\text { Christian }>\text { Muslim }\end{array}$} \\
\hline & & Muslim & $.90327(*)$ & \\
\hline & & Other & $.17688(*)$ & \\
\hline & Christian & Buddhist & .22858 & \\
\hline & & Muslim & $1.13185(*)$ & \\
\hline & & Other & $.40547(*)$ & \\
\hline & Muslim & Buddhist & $-.90327(*)$ & \\
\hline & & Christian & $-1.13185(*)$ & \\
\hline & & Other & $-.72639(*)$ & \\
\hline
\end{tabular}

* The mean difference is significant at the .05 level.

Table 9. One-Way analysis of variance summary for intuitive negotiation style

\begin{tabular}{|l|c|c|c|c|c|}
\hline & Sum of Squares & df & Mean Square & F & Sig. \\
\hline Between Groups & 20.874 & 3 & 6.958 & 28.266 & .000 \\
Within Groups & 148.925 & 605 & .246 & & \\
Total & 169.799 & 608 & & & \\
\hline
\end{tabular}

Table 10. Multiple Comparisons of Post Hoc Tests on Intuitive Negotiation Style for Religion

\begin{tabular}{|c|c|c|c|c|}
\hline Dependent Variable & Religion (I) & Religion (J) & Mean Difference (I-J) & Post Hoc Test \\
\hline Intuitive & Buddhist & Christian & .06486 & \multirow{3}{*}{ Buddhist $>$ Muslim } \\
\hline & & Muslim & $.74809\left(^{*}\right)$ \\
\hline & & Other & $.26964\left(^{*}\right)$ & \multirow{3}{*}{ Christian $>$ Muslim } \\
\hline & Christian & Buddhist & -.06486 & $.68323\left(^{*}\right)$ \\
\hline & & Muslim & $.20479\left(^{*}\right)$ \\
\hline & Muslim & Other & $-.74809\left(^{*}\right)$ \\
\hline & & Buddhist & $-.68323\left(^{*}\right)$ \\
\hline & & Christian & $-.47844(*)$ & \\
\hline
\end{tabular}

* The mean difference is significant at the .05 level. 